\title{
MEASURING THE EFFECTS OF MERGERS AND ACQUISITIONS ON THE ECONOMIC PERFORMANCE OF REAL ESTATE DEVELOPERS
}

\author{
Zhigang JIN a , Bo XIA $^{\text {b,*, Vera LI }}{ }^{\text {c, Heng LI }}{ }^{\text {, }}$, Martin SKITMORE ${ }^{\text {b }}$ \\ a College of Architecture and Environment, Sichuan University, Chengdu 610065, China \\ ${ }^{b}$ School of Civil Engineering and Built Environment, Queensland University of Technology, Gardens \\ Point, Brisbane, Australia \\ c School of Accountancy and Finance, The Hong Kong Polytechnic University, Hong Kong, China \\ ${ }^{d}$ Construction Virtual Prototyping Lab, Department of Building and Real Estate, The Hong Kong \\ Polytechnic University, Hong Kong, China
}

Received 21 January 2014; accepted 5 May 2014

\begin{abstract}
Real estate developers in China are using mergers and acquisitions (M\&As) to ensure their survival and competitiveness. However, no suitable method is yet available to assess whether such M\&As provide enhanced value for those involved. Using a hybrid method of data envelopment analysis (DEA) and Malmquist total factor productivity (TFP) indices, this paper evaluates the short and medium term effects of M\&As on acquirers' economic performance with a set of 32 M\&A cases occurring during 2000-2011 in China. The results of the analysis show that M\&As generally have a positive effect on acquirers' economic performance. Acquisitions on average experienced a steady growth in developer Malmquist TFP, a more progressive adoption of technology immediately after acquisition, a slight short-term decrease in technical efficiency after acquisition but followed by a marked increase in the longer term once the integration and synergy benefits were realised. However, there is no evidence to show whether developers achieved any short or long term scale efficiency improvements after M\&A. The findings of this study provide useful insights on developer M\&A performance from an efficiency and productivity perspective.
\end{abstract}

KEYWORDS: Mergers and acquisitions; Real estate; Developers; Efficiency; Total factor productivity; China

\section{INTRODUCTION}

Real estate is China's fastest-growing industry as its formation and development follows China's economic reform in the 1980's (Choi 1998). Since 2004, the Chinese government has enacted a series of macro-economic regulatory policies to mitigate the risk of a real estate bubble. This has resulted in a wave of mergers and acquisitions (M\&As) of developers in the industry, and both the number of deals and volume of developer M\&As have increased sharply since 2006 (see Table 1), making the industry one of the most M\&A active in China

Table 1. Chinese real estate M\&A deals from 2006 to 2011 (Jan to Feb)

\begin{tabular}{lllll}
\hline Year & No. of deals & $\begin{array}{l}\text { No. of deals } \\
\text { (disclosed) }\end{array}$ & $\begin{array}{l}\text { M\&A amount } \\
\text { (US \$M) }\end{array}$ & $\begin{array}{l}\text { Average M\&A amount } \\
\text { (US \$M) }\end{array}$ \\
\hline 2006 & 3 & 3 & 160.28 & 53.43 \\
2007 & 3 & 3 & 1540.42 & 513.47 \\
2008 & 4 & 2 & 512.00 & 256.00 \\
2009 & 20 & 20 & 2971.80 & 148.59 \\
2010 & 84 & 75 & 2582.44 & 34.43 \\
2011 (Jan-Feb) & 22 & 22 & 1149.87 & 52.27 \\
Total & 136 & 125 & 8916.81 & 71.33 \\
\hline
\end{tabular}

Source: Zero2IPO Group (2011)

\footnotetext{
* Corresponding author. E-mail: paul.xia@qut.edu.au
} 
today. However, it is not yet clear whether developer M\&As lead to better post-acquisition performance or not.

The most commonly used methods to evaluate M\&A performance in the business domain include event studies, cash flow analysis and market value frontiers (Franks, Harris 1989; Healy et al. 1992; Sudarsanam et al. 1996; Mitchell et al. 2004). However, as Antoniou and Zhao (2011) point out, these methods are unable to provide meaningful insights or usable information on the extent to which M\&As create value. Furthermore, in order to evaluate the M\&A performance, a single factor (e.g. cash flow, value added) is not enough to compare the acquirers' performance before and after a M\&A. Multiple inputs and outputs should be considered for a comprehensive evaluation.

Data Envelopment Analysis (DEA) is a powerful methodology for assessing the relative efficiencies of multi-input and multi-output production units. Established by Charnes et al. (1978) based on the work of Farrell (1957), DEA has the advantage of not needing to select a particular functional form, make distributional assumptions or set the relative weights of variables. It has good statistical characteristics and is a very convenient method for detecting efficiency and productivity changes in individual organisations (Charnes et al. 1978; Cooper et al. 2007a, 2008b), making it very suitable for evaluating and comparing the performance of developer M\&As.

However, DEA measures the efficiency and productivity of decision units for a specific period of time and does not allow any analysis of changes over time. Meanwhile, the Malmquist total factor productivity (TFP) indices can help evaluate the total factor productivity change of a particular organisation over a fixed period, although it could be applied equally well in other areas (Caves et al. 1982; Färe et al. 1994a,b; Cooper et al. 2007b; Kortelainen 2008). Malmquist indices have several desirable features and properties: (1) there is no need to make behavioural assumptions, such as cost minimisation or profit maximisation, which makes them useful when the producer's objectives differ, or are unknown or are unachieved; (2) no need to provide price information, which makes the indices of practical use when either prices do not exist, are distorted or have little economic meaning; and (3) they can easily be calculated by the DEA methodology (Caves et al. 1982; Färe et al. 1998). All these issues make the DEA-based Malmquist TFP Index very suitable for evaluating M\&A induced performance changes as a result of real estate acquisitions.
The purpose of this study is, therefore, to establish the extent to which developer M\&As increase the acquirers' economic performance using the DEA-based Malmquist TFP Index. The next section develops and explains the DEA-Malmquist method for assessing developer M\&A performance. This is followed by an illustration of the method and test on a set of 32 Chinese developer M\&As between 2000-2011. The results of the analysis are then presented prior to some concluding remarks.

\section{REVIEW OF POST-ACQUISITION PERFORMANCE EVALUATION}

Many studies have examined the stock returns of acquisitions to investigate the effect of M\&A transactions on acquisitions. The event-study methodology, first proposed by Fama et al. (1969) is often used. This focuses on the long-term (e.g. one to five year) effect following an event (e.g., a takeover) and can provide key evidence concerning market efficiency (Brown, Warner 1980; Fama 1991). However, the event-study methodology has several shortcomings. Firstly, for a long-term event study it is more difficult to isolate the takeover effects from many other strategic and operational decisions or changes in the financial policy arising in the long term. Secondly, benchmark performance often suffers from measurement or statistical problems (Barber, Lyon 1997). For example, according to Barber and Lyon (1997), cumulative abnormal returns (CAR), which is often used to investigate the effect of extraneous events on stock prices by calculating the sum of all the differences between the expected returns and the actual returns up to a given point in time, is a biased predictor for longterm event studies.

Two other main methods of assessing and calibrating post-event risk-adjusted performance have been adopted in the past to measure longrun abnormal stock returns: a characteristic-based matching approach and Jensen's alpha approach, which is also known as the calendar time portfolio approach (Fama 1998; Eckbo et al. 2000; Mitchell, Stafford 2000). However, despite extensive studies of these two types of long-term event study methods, there is still no clear preference (Kothari, Warner 2005). Both have low power against economically interesting null hypotheses and neither is immune from misspecification (Jegadeesh, Karceski 2004). Considering these power and specification problems, the challenge of refining long-term event methods remains (Kothari, Warner 2005). 


\section{THE DEA-MALMQUIST METHOD}

\subsection{Selection of performance evaluation indicators (inputs and outputs)}

In order to select appropriate input and output indicators for performance evaluation, a close examination of the real estate industry in China is required. Real estate development is a capital intensive industry that demands huge financial commitments to cover the high price of land acquisition and substantial expenditure in the construction process. This implies that one of the first requirements of a developer is a strong financial capability. To reflect this, the equity ratio (input 1) was selected as it reflects the financing capability and capital structure of the organisation. Accordingly, the stockholders return ratio (output 1) is adopted as an output indicator for assessing the contribution of capital input.

Furthermore, the production process of the real estate industry involves a long period of time and massive capital investment. Although property project presales can produce some capital in advance, developers still need to access further finance through other channels for the large amount of capital needed to cover construction costs. Therefore, the quick ratio (output 2), which measures the ability of an organisation to use its liquid capital to immediately overcome its current liabilities, is also adopted as an output indicator.

As property is expensive, the customers' purchasing intentions are normally influenced by their expected income and attitude towards future economic prospects. Developers, on the other hand, need to formulate appropriate operation strategies depending on the economic situation. To reflect the impact of this, inventory turnover (input 2) - representing the property selling condition and resources commitment - is used as an input indicator. Return on sales (output 3 ) is the corresponding output indicator.

In China's real estate industry, land is generally regarded as a core production material and long-term asset, and developers always experience fierce competition and need a substantial amount of capital commitment for its purchase. To raise the funds needed, developers generally use land as a mortgage tool for obtaining quick cash. Additionally, developers in China use presales (such as a $20 \%$ to $30 \%$ down payment) to lower investment barriers for individuals and appeal to more consumers to buy properties. By using these methods, developers improve their cash flow and transfer the risks involved in money collection to financial institutions such as banks. To reflect this aspect of developer performance, the receivable turnover ratio (input 3) is adopted as an input indicator, with the cash flow ratio (output 4) as an output indicator.

Finally, due to the ferocity of competition, developers need to compete in price, quality, service, product delivery, etc. Specifically, requirements such as vast investment resources and long construction periods make the profitability of developers particularly vulnerable to fluctuations in the economic environment and the market. To reflect the effect of market competition on developer performance, the return of assets (output 5) is used as an output indicator.

In short, three input indicators (Stockholder Equity Ratio, Inventory Turnover and Receivable Turnover Ratio) and five output indicators (Return on Equity, Return on Sales, Quick Ratio, Cash Flow Ratio and Return on Assets) are used in the analysis. It should be noted that all the output indictors are related to economic performance, and it is not the intention to investigate social or environmental performance at this stage.

\subsection{DEA efficiency estimation}

DEA is a modern frontier analysis method for efficiency estimation, comprising technical efficiency, pure technical, allocative, scale, cost and revenue efficiency (Cooper et al 2007b). The efficient value range is from 0 to 1 , where 1 is regarded as the most efficient. In this paper, technical efficiency, pure technical efficiency and scale efficiency are used to measure acquirer efficiency. Technical efficiency is measured by using an input-oriented model (Shepherd 1970). Assume Decision Making Unit (DMU) $i$ uses M inputs $x_{i}^{t}$ to generate $N$ outputs $y_{i}^{t}$ in period $t$. The production technology of period $\mathrm{t}$ can be modelled by an input function. For any $y^{t} \in \mathbb{R}_{+}^{\mathrm{N}}, V_{r}^{t}\left(y^{t}\right)$ denotes the subset of all input vectors $x^{t} \in \mathbb{R}_{+}^{M}$ which yield at least $y^{t}$, using a production technology characterised by returns to scale of type $r$, where $r=c=$ constant returns to scale (CRS), $r=v=$ variable returns to scale (VRS), and $r=n=$ non-increasing returns to scale (NIRS). The input-oriented distance function is:

$$
\begin{aligned}
& D_{r}^{t}\left(x_{i}^{s}, y_{i}^{s}\right)=\sup \left\{\theta_{i}^{s}:\left(\frac{x_{i}^{s}}{\theta_{i}^{s}}, y_{i}^{s}\right) \epsilon V_{r}^{t}\left(y_{i}^{s}\right)\right\} \\
& =\left(\inf \left\{\theta_{i}^{s}:\left(\theta_{i}^{s} x_{i}^{s}, y_{i}^{s}\right)\right\}\right)^{-1},
\end{aligned}
$$

where: $\left(x_{i}^{s}, y_{i}^{s}\right)$ is the input and output vector for DMU $i$ during period $s$. 
Technical efficiency $T E_{r}^{t}\left(x_{i}^{t}, y_{i}^{t}\right)$ is thus defined as $T E_{r}^{t}\left(x_{i}^{t}, y_{i}^{t}\right)=1 / D_{r}^{t}\left(x_{i}^{t}, y_{i}^{t}\right)$. CRS technical efficiency is measured for each DMU by solving a linear programming problem:

$$
\left(D_{c}^{t}\left(x_{i}^{s}, y_{i}^{s}\right)\right)^{-1}=T E_{c}^{t}\left(x_{i}^{t}, y_{i}^{t}\right)=\min \theta_{i}^{t},
$$

Subject to: $Y^{t} \lambda_{i}^{t} \geq y_{i}^{t}$,

$$
X^{t} \lambda_{i}^{t} \leq \theta_{i}^{t} x_{i}^{t} \text { and }
$$

$\lambda_{i}^{t} \geq 0$,

where: $X^{t}$ is a $M \times I$ input matrix and $Y^{t}$ an $N \times I$ output matrix for all DMUs; $\lambda_{i}^{t}$ is an $I \times 1$ intensity vector; and $I=$ the number of DMUs in the sample $(i=1,2, \ldots, I)$. This estimation (with the $\lambda_{i}^{t}$ constrained to be non-negative) generates a CRS frontier.

Technical efficiency can be divided into pure technical efficiency $T E_{v}^{t}\left(x_{i}^{t}, y_{i}^{t}\right)$ (technical efficiency relative to a VRSfrontier) and scale efficiency $S E^{t}\left(x_{i}^{t}, y_{i}^{t}\right)$, as $T E_{c}^{t}\left(x_{i}^{t}, y_{i}^{t}\right)=T E_{v}^{t}\left(x_{i}^{t}, y_{i}^{t}\right) S E^{t}\left(x_{i}^{t}, y_{i}^{t}\right)$. These are separated by solving equation (2) with the additional constraint: $\sum_{i=1}^{I} \lambda_{i}^{t}=1$ for a VRS frontier, and with the constraint $\sum_{i=1}^{I} \lambda_{i}^{t} \leq 1$ for a NIRS frontier. Pure technical efficiency is the solution to the VRS problem, and scale efficiency is then obtained by $S E^{t}\left(x_{i}^{t}, y_{i}^{t}\right)=T E_{c}^{t}\left(x_{i}^{t}, y_{i}^{t}\right) / T E_{v}^{t}\left(x_{i}^{t}, y_{i}^{t}\right)$. If $S E^{t}\left(x_{i}^{t}, y_{i}^{t}\right)=1$, CRS are indicated. If $S E^{t}\left(x_{i}^{t}, y_{i}^{t}\right) \neq 1$ and NIRS efficiency $=T E_{v}^{t}$, DRS are indicated; if $S E^{t}\left(x_{i}^{t}, y_{i}^{t}\right) \neq 1$ and NIRS efficiency $\neq T E_{v}^{t}$ then IRS are present.

\subsection{DEA-based Malmquist analysis of productivity}

The Malmquist index approach is adopted to measure the total factor productivity (TFP) change of DMUs over time. The description below draws primarily upon the work of Färe et al. (1994a, 1998) and recaps some of the discussion from Coelli et al. (2005). The Malmquist TFP change index (outputorientated) between period $s$ (the start period) and period $t$ is given by (Caves et al. 1982).

$$
M_{0}\left(x_{s}, y_{s}, x_{t}, y_{t}\right)=\left[\frac{D_{0}^{s}\left(x_{t}, y_{t}\right)}{D_{0}^{s}\left(x_{s}, y_{s}\right)} \times \frac{D_{0}^{t}\left(x_{t}, y_{t}\right)}{D_{0}^{t}\left(x_{s}, y_{s}\right)}\right]^{1 / 2} \text {. }
$$

The distance function $D_{0}^{s}\left(x_{s}, y_{s}\right)=\inf$ $\left\{\varnothing:\left(x^{s}, y^{s} / \varnothing\right) \in S^{s}\right\}$ is defined as the reciprocal of the "maximum" proportional expansion of the output vector $y^{s}$ in given inputs $x^{s}$. Similarly, the distance function $D_{0}^{s}\left(x_{t}, y_{t}\right)=\inf \left\{\varnothing:\left(x^{t}, y^{t} / \varnothing\right) \in S^{\mathrm{s}}\right\}$ represents the distance from period t to the period s technology. A value of $M_{0}$ larger than one means that the TFP grows from period $s$ to period $t$, otherwise a decline in TFP is indicated.

By rearranging function 3, the TFP index can be decomposed into the product of the technical change index and the technical efficiency change index as:

$M_{0}\left(x_{s}, y_{s}, x_{t}, y_{t}\right)=\frac{D_{0}^{t}\left(x_{t}, y_{t}\right)}{D_{0}^{s}\left(x_{s}, y_{s}\right)}\left[\frac{D_{0}^{s}\left(x_{t}, y_{t}\right)}{D_{0}^{t}\left(x_{t}, y_{t}\right)} \times \frac{D_{0}^{s}\left(x_{s}, y_{s}\right)}{D_{0}^{t}\left(x_{s}, y_{s}\right)}\right]^{1 / 2}$.

In equation (4), the ratio outside the square brackets is actually the efficiency change (EC), which evaluates the change in the output-oriented measure of Farrell technical efficiency between periods $s$ and $t$ :

$$
E C=\frac{D_{0}^{t}\left(x_{t}, y_{t}\right)}{D_{0}^{s}\left(x_{s}, y_{s}\right)} .
$$

The remaining part of equation (4) concerns technical change (TC), which measures the geometric mean of the shift in technology between the two periods $s$ and $t$ :

$$
T C=\left[\frac{D_{0}^{s}\left(x_{t}, y_{t}\right)}{D_{0}^{t}\left(x_{t}, y_{t}\right)} \times \frac{D_{0}^{s}\left(x_{s}, y_{s}\right)}{D_{0}^{t}\left(x_{s}, y_{s}\right)}\right]^{1 / 2} .
$$

Furthermore, Färe et al. (1994b) decomposed technical efficiency change into "pure" technical efficiency change and scale efficiency change. The pure efficiency change (PEC) is defined in equation (7) as:

$$
P E C=\frac{D_{0 v}^{t}\left(x_{t}, y_{t}\right)}{D_{0 v}^{s}\left(x_{s}, y_{s}\right)}
$$

and the scale efficiency change (SEC) is written as:

$$
S E C=\left[\begin{array}{l}
\frac{D_{0 v}^{t}\left(x_{t}, y_{t}\right) / D_{0 c}^{t}\left(x_{t}, y_{t}\right)}{D_{0 v}^{t}\left(x_{s}, y_{s}\right) / D_{0 c}^{t}\left(x_{s}, y_{s}\right)} \times \\
\frac{D_{0 v}^{s}\left(x_{t}, y_{t}\right) / D_{0 c}^{s}\left(x_{t}, y_{t}\right)}{D_{0 v}^{s}\left(x_{s}, y_{s}\right) / D_{0 c}^{s}\left(x_{s}, y_{s}\right)}
\end{array}\right]^{1 / 2} .
$$

The SEC is actually the geometric mean of two SEC measures relative to period $t$ and $s$ technology respectively.

The Malmquist TFP index (distance measures) in equation (3) can be calculated by using a DEAlike linear programming methodology (Färe et al. 1994a). For the organisation $i$-th, four distance functions need to be calculated to measure the TFP change between two periods. These four distances can be obtained by the four linear programming problems (equations 9-12):

$$
\left[D_{0}^{t}\left(x_{t}, y_{t}\right)\right]^{-1}=\max _{\varnothing, \lambda} \varnothing
$$




$$
\begin{aligned}
& s t-\varnothing x_{i t}+X_{T} \lambda \geq 0, \\
& y_{i t}-Y_{t} \lambda \geq 0, \\
& \lambda \geq 0 \\
& {\left[D_{0}^{s}\left(x_{s}, y_{s}\right)\right]^{-1}=\max _{\varnothing, \lambda} \varnothing,} \\
& s t-\varnothing x_{i s}+X_{S} \lambda \geq 0, \\
& y_{i s}-Y_{s} \lambda \geq 0 \\
& \lambda \geq 0 \\
& {\left[D_{0}^{t}\left(x_{s}, y_{t}\right)\right]^{-1}=\max _{\varnothing, \lambda} \varnothing,} \\
& s t-\varnothing x_{i s}+X_{T} \lambda \geq 0, \\
& y_{i s}-Y_{t} \lambda \geq 0 \\
& \lambda \geq 0
\end{aligned}
$$

and

$$
\begin{aligned}
& {\left[D_{0}^{s}\left(x_{t}, y_{t}\right)\right]^{-1}=\max _{\varnothing, \lambda} \varnothing,} \\
& \text { st }-\varnothing x_{i t}+X_{S} \lambda \geq 0, \\
& y_{i t}-Y_{s} \lambda \geq 0, \\
& \lambda \geq 0,
\end{aligned}
$$

where: $\theta$ is a scalar and $\lambda$ is a $I \times l$ vector of constants. The value of $\theta$ is the efficiency score for the $i$-th organisation. To calculate the PEC index (equation 7) and the SEC index (equation 8), two additional LPs are required on the basis of the LPs 9 and10 respectively, with only the convexity restriction $(\Pi \lambda=1)$ added to each. The DEAP version 2.1 is used to evaluate the DEA and Malmquist index. Details of DEAP version 2.1 are provided in Coelli (1996).

\subsection{Estimation windows}

To compare the value of the Malmquist TFP index before and after acquisition, three estimation windows are established that include four time points such as one year prior to acquisition $(t-1)$, acqui- sition announcement $(t+0)$, one year after acquisition $(t+1)$ and three years after acquisition $(t+3)$. The two windows: window (1) from $(t-1)$ to $(t+$ $1)$; and window (2) from $(t-1)$ to $(t+3)$ represent the short-term and relatively long-term windows of the M\&As respectively.

\section{ILLUSTRATIVE EXAMPLE AND TESTING}

\subsection{Data sources and sampling}

M\&A transactions are identified from the Thomson Financial Securities Data's SDC and Bloomberg database. For the Chinese real estate industry, M\&A information can be obtained from (1) the China Real Estate Industry Research Database, and (2) the China-listed Firm's Merger \& Acquisition Dataset. A total of 32 Chinese developer M\&As cases were selected at random according to the following criteria: (1) there must be a transfer of ownership between acquirers and their targets; (2) acquirers are from the real estate industry; (3) their operation and financial data are available

\begin{tabular}{|c|c|c|c|c|c|c|c|}
\hline \multirow[t]{2}{*}{ Items } & \multicolumn{3}{|l|}{ Acquirers } & \multicolumn{3}{|l|}{ Targets } & \multirow{2}{*}{$\begin{array}{l}\text { Difference: } \\
\text { acquirer/target }\end{array}$} \\
\hline & Mean & Min & $\operatorname{Max}$ & Mean & Min & Max & \\
\hline Total assets (Yuan) & $9.07 \mathrm{E}+09$ & $3.63 \mathrm{E}+07$ & $5.98 \mathrm{E}+10$ & $3.28 \mathrm{E}+09$ & 610441 & $5.48 \mathrm{E}+10$ & 2.77 \\
\hline Debt (Yuan) & $5.63 \mathrm{E}+09$ & $1.59 \mathrm{E}+07$ & $3.95 \mathrm{E}+10$ & $2.40 \mathrm{E}+09$ & 514617 & $3.35 \mathrm{E}+10$ & 2.35 \\
\hline Cash (Yuan) & $1.40 \mathrm{E}+09$ & 3993385 & $8.92 \mathrm{E}+09$ & $3.99 \mathrm{E}+08$ & $-2.31 \mathrm{E}+08$ & $6.03 \mathrm{E}+09$ & 3.51 \\
\hline Market value (Yuan) & $1.15 \mathrm{E}+10$ & $1.77 \mathrm{E}+08$ & $6.76 \mathrm{E}+10$ & $5.12 \mathrm{E}+09$ & 71642.25 & $5.48 \mathrm{E}+10$ & 2.25 \\
\hline Financial leverages & 11.8840 & 1.6700 & 74.3200 & 12.2216 & 0.0073 & 58.3294 & 0.97 \\
\hline Tobin's' Q & 2.9390 & 1.5500 & 7.0700 & 5.2771 & 1.5615 & 37.0533 & 0.56 \\
\hline Cash \& growth & 0.3963 & 0.0800 & 1.4700 & 2.2948 & 0.0426 & 37.1513 & 0.17 \\
\hline Return on equity & 0.1150 & 0.0000 & 0.4400 & 0.1885 & 0.0198 & 0.8881 & 0.61 \\
\hline Return on assets & 0.0588 & 0.0000 & 0.3600 & 0.0792 & 0.0019 & 0.3585 & 0.74 \\
\hline
\end{tabular}
in the databases.

\subsection{Summary statistics}

The financial operational indicators of acquirers and target developers are summarised in Table 3, which provides a general background and context of the sample cases' performances. This shows that acquirers are 2.77, 2.35, 3.51 and 2.25 times larger than the target developers on total assets, debt, cash and market value respectively. In contrast, the acquirers have relatively smaller financial leverage, Tobin's Q, Cash \& Growth, return on equity, and return on assets. This first indicates that the management efficiency and profitability of the tar-

Table 2. Operational indicators of acquirer and target developers

Note: Tobin's Q is an indicator generally used to measure the management efficiency of organisations (Lang et al. 1989; Servaes 1991; Chung, Pruitt 1994). Tobin's Q = (the organisation's market value + liquidation value of preferred stock DEBT)/ Total assets; If T's Q less than one, an inefficient management is indicated. Cash \& growth is a useful indicator to identify any agent problems (Jensen 1986; Lang et al. 1991). High levels of cash flow, but low growth opportunities imply the presence of an agency problem. 
Table 3. Input and output indicators (32 samples)

\begin{tabular}{|c|c|c|c|c|c|c|c|c|c|c|c|c|}
\hline \multirow[t]{2}{*}{ Items } & \multicolumn{3}{|l|}{$t-1$} & \multicolumn{3}{|l|}{$t+0$} & \multicolumn{3}{|l|}{$t+1$} & \multicolumn{3}{|l|}{$t+3$} \\
\hline & Mean & Min & $\operatorname{Max}$ & Mean & Min & $\operatorname{Max}$ & Mean & Min & $\operatorname{Max}$ & Mean & Min & $\operatorname{Max}$ \\
\hline Equity ratio & 0.36 & -0.79 & 0.89 & 0.36 & -0.74 & 0.75 & 0.39 & 0.21 & 0.75 & 0.38 & 0.18 & 0.71 \\
\hline Inventory turnover & 0.94 & 0.03 & 6.55 & 0.67 & 0.14 & 3.48 & 0.49 & 0.02 & 2.31 & 0.44 & 0 & 3.76 \\
\hline $\begin{array}{l}\text { Receivables turnover } \\
\text { ratio }\end{array}$ & 227 & 1 & 5270 & 139 & 4 & 1990 & 117 & 2 & 1098 & 241 & 3 & 2141 \\
\hline Return of equity & -0.06 & -1.5 & 0.33 & 0.12 & 0 & 0.44 & 0.12 & 0 & 0.55 & 0.11 & -0.02 & 0.38 \\
\hline Return on sales & 0.23 & -0.44 & 0.51 & 0.26 & 0.09 & 0.44 & 0.32 & 0.07 & 0.71 & 0.3 & 0.08 & 0.56 \\
\hline Quick ratio & 0.69 & 0.08 & 2.11 & 0.58 & 0.1 & 1.45 & 0.72 & 0.09 & 2.33 & 0.68 & 0.22 & 1.79 \\
\hline Cash flow ratio & -0.04 & -1.37 & 0.78 & 0.04 & -0.89 & 1.79 & -0.13 & -1.19 & 0.75 & -0.1 & -0.45 & 0.45 \\
\hline Return of assets & 0.02 & -0.23 & 0.15 & 0.06 & 0 & 0.36 & 0.05 & 0 & 0.31 & 0.04 & -0.01 & 0.1 \\
\hline
\end{tabular}

get developers is much higher than that of the acquirers in the sample. Second, it clearly shows that that the M\&As generally occur between acquirers with a large business scale and target developers with high managerial efficiency and profitability.

The information relating to the input and output indicators is summarised in Table 4. For the input indicators, the equity ratio increased slightly from 0.36 in $t-1$ to 0.38 in $t-3$, indicating an increased capital commitment from acquirers after acquisition. The acquirers' average inventory turnover decreased significantly from 0.94 in pe$\operatorname{riod} t-1$ to 0.44 in period $t+3$. The receivables turnover ratio decreased dramatically from 227 to 117 from $t-1$ to $t+1$, but then increased slightly to 241 in $t+3$. In terms of output indicators, both ROE and ROS increased significantly from the pre-acquisition to post-acquisition phase. The acquirer's average quick ratio experienced little fluctuation from $t-1$ to $t+3$. Conversely, the cash flow ratio was highly volatile during the same period. Finally, there was a substantial rise in the acquirers' average return on assets from $t-1$ to $t+3$, increasing to a mean 0.06 in the short term and 0.04 in the longer term. All in all, the selected input and output indicators mainly show a trend of better financial performance of the sample cases after the M\&As with five out of eight indicators recording an increased value. Of the other three indicators, one has only a slight decrease from 0.69 at $t-1$ to 0.68 at $t+1$, with the remaining two in an obvious relative decline.

The efficiency of acquirers measured by the DEA method is illustrated in Table 5. Their average technical efficiency decreased significantly from 0.93 in $t-1$ to 0.74 in $t+3$, with the lowest being 0.72 in $t+1$. This means that technical efficiency declined sharply in the short-term after acquisition, but recovered slightly since the realisation of the synergy and integration benefits of M\&A in longer term. Similarly, pure technical efficiency sharply declined from 0.94 to 0.81 during $t-1$ to $t+1$, but rose to 0.86 in $t+3$. In contrast, scale efficiency experienced a continual decline in both the short and long-term, dropping gradually from 0.98 to $0.85-$ implying that no economies of scale were achieved.

Table 4. Efficiency of acquirers in different periods (32 samples)

\begin{tabular}{|c|c|c|c|c|c|c|c|c|c|c|c|c|}
\hline \multirow[t]{2}{*}{ Organization } & \multicolumn{4}{|c|}{ Technical efficiency } & \multicolumn{4}{|c|}{ Pure technical efficiency } & \multicolumn{4}{|c|}{ Scale efficiency } \\
\hline & $t-1$ & $t+0$ & $t+1$ & $t+3$ & $t-1$ & $t+0$ & $t+1$ & $t+3$ & $t-1$ & $t+0$ & $t+1$ & $t+3$ \\
\hline 1 & 0.94 & 0.83 & 0.62 & 0.53 & 0.99 & 0.92 & 0.67 & 0.70 & 0.96 & 0.90 & 0.93 & 0.76 \\
\hline 2 & 0.90 & 1.00 & 0.65 & 0.48 & 0.91 & 1.00 & 0.69 & 0.65 & 0.98 & 1.00 & 0.95 & 0.74 \\
\hline 3 & 1.00 & 0.62 & 0.61 & 0.75 & 1.00 & 1.00 & 0.81 & 1.00 & 1.00 & 0.62 & 0.75 & 0.75 \\
\hline 4 & 0.89 & 1.00 & 0.50 & 0.42 & 0.97 & 1.00 & 0.52 & 0.58 & 0.92 & 1.00 & 0.97 & 0.73 \\
\hline 5 & 1.00 & 1.00 & 0.58 & 0.79 & 1.00 & 1.00 & 0.59 & 0.85 & 1.00 & 1.00 & 0.99 & 0.92 \\
\hline 6 & 0.94 & 0.67 & 1.00 & 1.00 & 0.97 & 0.79 & 1.00 & 1.00 & 0.97 & 0.86 & 1.00 & 1.00 \\
\hline 7 & 1.00 & 0.77 & 1.00 & 0.36 & 1.00 & 1.00 & 1.00 & 0.82 & 1.00 & 0.77 & 1.00 & 0.44 \\
\hline 8 & 1.00 & 1.00 & 1.00 & 0.59 & 1.00 & 1.00 & 1.00 & 0.83 & 1.00 & 1.00 & 1.00 & 0.71 \\
\hline 9 & 1.00 & 1.00 & 1.00 & 1.00 & 1.00 & 1.00 & 1.00 & 1.00 & 1.00 & 1.00 & 1.00 & 1.00 \\
\hline 10 & 1.00 & 1.00 & 0.76 & 0.49 & 1.00 & 1.00 & 0.78 & 0.58 & 1.00 & 1.00 & 0.97 & 0.84 \\
\hline 11 & 0.64 & 0.76 & 0.66 & 0.51 & 0.65 & 0.78 & 0.68 & 0.69 & 0.99 & 0.98 & 0.97 & 0.73 \\
\hline 12 & 0.86 & 0.90 & 0.75 & 0.56 & 0.91 & 0.96 & 0.78 & 0.76 & 0.94 & 0.95 & 0.97 & $\begin{array}{l}0.73 \\
\text { ntinued) }\end{array}$ \\
\hline
\end{tabular}




\begin{tabular}{|c|c|c|c|c|c|c|c|c|c|c|c|c|}
\hline \multirow[t]{2}{*}{ Organization } & \multicolumn{4}{|c|}{ Technical efficiency } & \multicolumn{4}{|c|}{ Pure technical efficiency } & \multicolumn{4}{|c|}{ Scale efficiency } \\
\hline & $t-1$ & $t+0$ & $t+1$ & $t+3$ & $t-1$ & $t+0$ & $t+1$ & $t+3$ & $t-1$ & $t+0$ & $t+1$ & $t+3$ \\
\hline \multicolumn{13}{|l|}{ (Continued) } \\
\hline 13 & 1.00 & 0.89 & 0.78 & 1.00 & 1.00 & 1.00 & 1.00 & 1.00 & 1.00 & 0.89 & 0.78 & 1.00 \\
\hline 14 & 1.00 & 1.00 & 0.64 & 0.62 & 1.00 & 1.00 & 0.86 & 1.00 & 1.00 & 1.00 & 0.75 & 0.62 \\
\hline 15 & 1.00 & 0.97 & 0.41 & 1.00 & 1.00 & 1.00 & 0.45 & 1.00 & 1.00 & 0.97 & 0.91 & 1.00 \\
\hline 16 & 1.00 & 1.00 & 1.00 & 0.85 & 1.00 & 1.00 & 1.00 & 0.98 & 1.00 & 1.00 & 1.00 & 0.86 \\
\hline 17 & 1.00 & 1.00 & 0.70 & 1.00 & 1.00 & 1.00 & 0.88 & 1.00 & 1.00 & 1.00 & 0.80 & 1.00 \\
\hline 18 & 0.93 & 1.00 & 0.80 & 0.67 & 0.94 & 1.00 & 0.92 & 0.75 & 1.00 & 1.00 & 0.87 & 0.90 \\
\hline 19 & 0.51 & 0.57 & 0.37 & 0.29 & 0.54 & 0.63 & 0.50 & 0.49 & 0.96 & 0.91 & 0.74 & 0.59 \\
\hline 20 & 1.00 & 1.00 & 0.98 & 0.55 & 1.00 & 1.00 & 1.00 & 0.68 & 1.00 & 1.00 & 0.98 & 0.82 \\
\hline 21 & 1.00 & 1.00 & 0.60 & 1.00 & 1.00 & 1.00 & 0.62 & 1.00 & 1.00 & 1.00 & 0.97 & 1.00 \\
\hline 22 & 1.00 & 0.73 & 0.57 & 0.72 & 1.00 & 1.00 & 0.66 & 0.75 & 1.00 & 0.73 & 0.87 & 0.97 \\
\hline 23 & 1.00 & 1.00 & 0.91 & 0.96 & 1.00 & 1.00 & 1.00 & 1.00 & 1.00 & 1.00 & 0.91 & 0.96 \\
\hline 24 & 0.65 & 0.91 & 0.62 & 0.74 & 0.71 & 0.96 & 0.66 & 0.79 & 0.91 & 0.95 & 0.93 & 0.94 \\
\hline 25 & 1.00 & 1.00 & 1.00 & 1.00 & 1.00 & 1.00 & 1.00 & 1.00 & 1.00 & 1.00 & 1.00 & 1.00 \\
\hline 26 & 1.00 & 0.52 & 0.53 & 0.93 & 1.00 & 0.82 & 0.89 & 0.97 & 1.00 & 0.64 & 0.60 & 0.95 \\
\hline 27 & 0.56 & 0.57 & 0.34 & 1.00 & 0.62 & 0.68 & 0.60 & 1.00 & 0.91 & 0.83 & 0.57 & 1.00 \\
\hline 28 & 1.00 & 1.00 & 0.62 & 0.65 & 1.00 & 1.00 & 0.92 & 0.82 & 1.00 & 1.00 & 0.68 & 0.79 \\
\hline 29 & 1.00 & 1.00 & 0.76 & 1.00 & 1.00 & 1.00 & 0.89 & 1.00 & 1.00 & 1.00 & 0.85 & 1.00 \\
\hline 30 & 0.86 & 1.00 & 1.00 & 1.00 & 0.87 & 1.00 & 1.00 & 1.00 & 0.99 & 1.00 & 1.00 & 1.00 \\
\hline 31 & 0.96 & 0.80 & 0.81 & 0.69 & 1.00 & 0.81 & 1.00 & 0.85 & 0.96 & 0.98 & 0.81 & 0.82 \\
\hline 32 & 1.00 & 1.00 & 0.44 & 0.68 & 1.00 & 1.00 & 0.50 & 0.92 & 1.00 & 1.00 & 0.89 & 0.74 \\
\hline Mean & 0.93 & 0.89 & 0.72 & 0.74 & 0.94 & 0.95 & 0.81 & 0.86 & 0.98 & 0.94 & 0.89 & 0.85 \\
\hline Max & 1.00 & 1.00 & 1.00 & 1.00 & 1.00 & 1.00 & 1.00 & 1.00 & 1.00 & 1.00 & 1.00 & 1.00 \\
\hline Min & 0.51 & 0.52 & 0.34 & 0.29 & 0.54 & 0.63 & 0.45 & 0.49 & 0.91 & 0.62 & 0.57 & 0.44 \\
\hline
\end{tabular}

\subsection{Productivity measuring result analysis}

The Malmquist TFP index of each acquirer is provided in Table 6. In terms of average value during $t-0$ to $t+3,17$ organisations had TFP growth, while the remaining 15 experienced a decline in productivity. Acquirer 29, with a TFP index of 2.24 (TEC * TC $=1$ * 2.24) had the most productivity growth - attributed to considerable technical improvement after acquisition - with other indices such as TEC, PEC and SEC remaining unchanged. In contrast, Acquirer 8 and Acquirer 4 had the poorest performance, with a mean TFP of 0.66 . Both these organisations experienced a dramatic decrease in technical efficiency and technology during acquisition. Other acquirers' performance can be understood in a similar way based on the TFP index changes. For example, Acquirers 15, 16 and 20 experienced TFP increases for periods $t+0, t+1$ and $t+3$ respectively, implying a shortterm productivity growth through the M\&A but reducing in the long-term. Acquirer 29's TEC of 1.32 $(\mathrm{TEC}=\mathrm{PEC} * \mathrm{SEC}=1.12 * 1.17)$ indicates that its pure technical efficiency and scale efficiency had both also made some progress.

It is noticeable that the mean Malmquist TFP index is highest (1.26) in the M\&A year $(t+0)$, and then decreased significantly to 0.81 in the following year $(t+1)$. In the longer term after acquisition $(t$ +3 ), the acquirers' mean TFP improved slightly to 1.02. The reasons for these changes can be identified from the TEC and TC perspectives: The acquirers' technology had the largest upgrade in $t+0$, with a slight increase at $t+1$ and followed by a slight decrease by $t+3$. In contrast, the mean technical efficiency of the acquirers markedly declined in both $t+$ 0 (0.96) and $t+1$ (0.79), but rose in $t+3$ (1.03). This clearly suggests, therefore, that the M\&As improved acquirers' technology in the short-term was due to a greater commitment of resources, but the growth began to diminish in the longer term as the effect of the M\&As on resource investment weakened. Meanwhile, technical efficiency decreased in $t+0$ and $t+$ 1 because of organisational transition in the shortterm while, in the longer term, technical efficiency increased as the synergy and integration benefits were realised. Similarly, PEC can be interpreted in the same way as TEC. Surprisingly, neither short nor long term increases in scale efficiencies were realised after the M\&As, which is consistent with previous scale efficiency analysis results. The reason for this is probably due to the real estate industry's unique characteristics of localisation and unmovable products. 


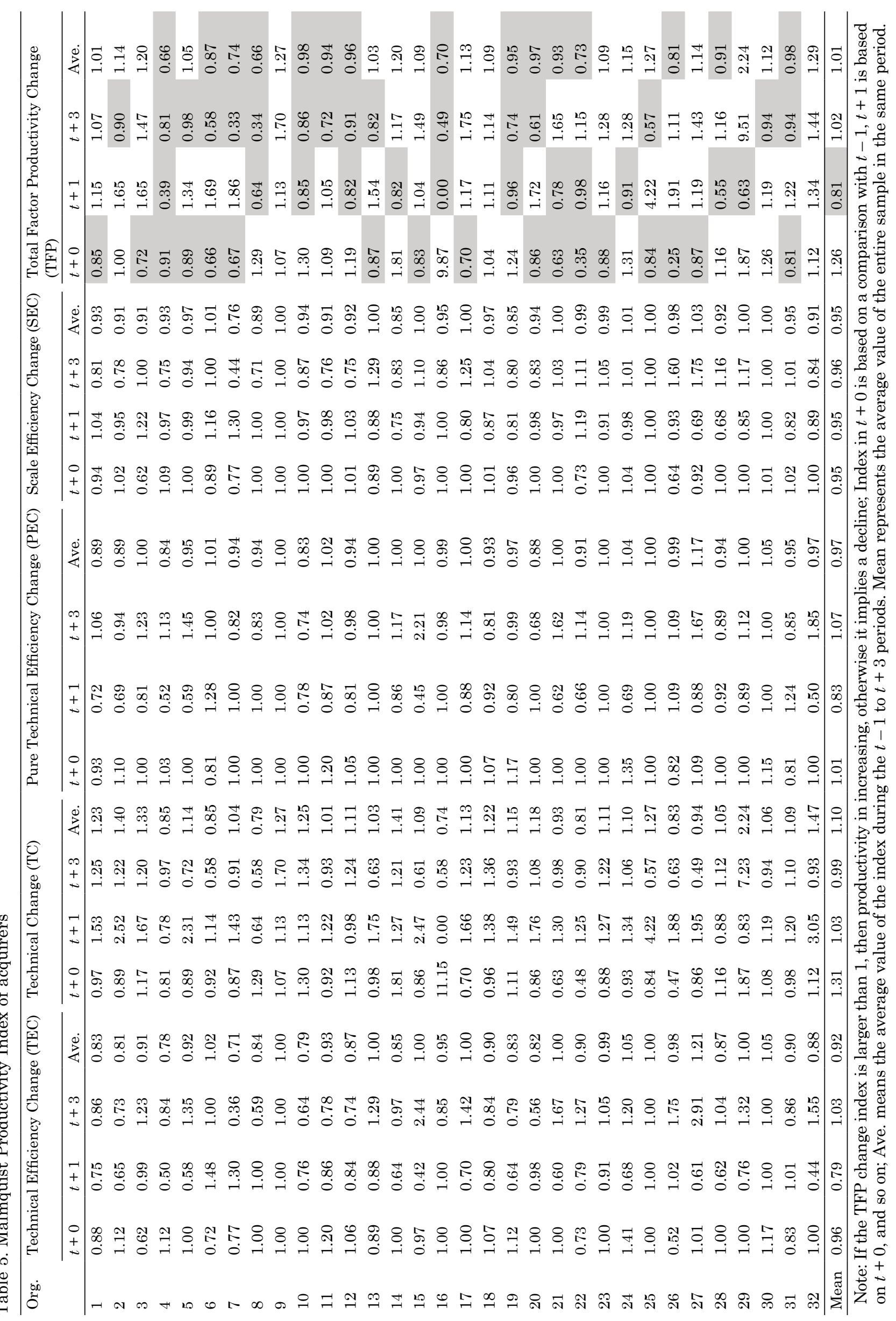




\section{CONCLUSION}

This paper uses a synthesis of DEA and Malmquist index methods to investigate the efficiency and productivity changes of real estate acquirers, as illustrated and tested with a sample of 32 M\&A cases from the Chinese real estate industry. The statistical analysis indicates that the industry has been experiencing a "big fish eats fingerling" style of acquisition, in which big developers with large amounts of cash acquire target developers with high development potential. The analysis shows that the financial performance of most of the sample acquirers improved after the M\&As. For those that experienced poorer performance after the M\&As, the major reason appears to be inefficient management during their transitional integration. The productivity analysis indicates a trend of better performance after the M\&As, which is consistent with the result of the statistical analysis and provide a clear answer to the research question of this paper.

However, the results of the efficiency analysis present a slightly different picture. On the one hand, technology adoption increases in the short-term immediately after the M\&As, due to the newly inputted resources at that time, but gradually declines as the new technology beds in. On the other hand, technical efficiency decreases immediately after the M\&As, which is probably due to inefficient management of the integration process needed as a result of the M\&As, then it increases gradually over time when the integration of the transition becomes more smooth. Furthermore, no economies of scale were found from the results of the efficiency analysis, which nevertheless provided a number of practical implications. First, it is suggested that the acquirers maintain a continuous investment in technology after the M\&As in order to enable a consistent level of technical commitment. Second, integration should be managed more efficiently in order to speed up the transitional process for improved technical efficiency. Finally, as M\&As are not able to positively affect economies of scale, other means, such as better marketing performance or better procurement, should be applied.

Overall, the findings of this research reflect the characteristics of the real estate industry in China in that M\&As provide a number of value-enhancing results for acquirers, but with no significant economies of scale due to increased organisation size. It should be pointed out that the results of the analysis depend on the selection of specific inputs and outputs indicators and it is therefore possible to obtain different results by changing the input and output indicators used. Additionally, the selection of different sample cases may also result in different outcomes. As there are more than 100 China real estate M\&As cases from 2006 to 2011, the detailed findings from the 32 sample cases may not necessarily generalise to the China's real estate industry overall. Nevertheless, the method used in this paper provides a useful and valid measure of developer M\&A performance from an efficiency and productivity perspective and provides valuable insights on the general consequences of M\&A decisions in the real estate industry in China and elsewhere.

\section{REFERENCES}

Antoniou, A. P.; Zhao, H. 2011. Measuring the economic gains of mergers and acquisitions: is it time for a change?, The Capco Institute Journal of Financial Transformation 32: 159-168. http://dx.doi. org/10.2139/ssrn.579841

Barber, B. M.; Lyon, J. D. 1997. Detecting long-run abnormal stock returns: the empirical power and specification of test statistics, Journal of Financial Economics 43: 341-372. http://dx.doi.org/10.1016/ S0304-405X(96)00890-2

Brown, S.; Warner, J. 1980. Measuring security price performance, Journal of Financial Economics 8: 205258. http://dx.doi.org/10.1016/0304-405X(80)90002-1

Caves, D. W.; Christensen, L. R.; Diewert, W. E. 1982. The economic theory of index numbers and the measurement of input, output and productivity, Econometrica 50: 1393-1414. http://dx.doi.org/10.2307/1913388

Charnes, A.; Cooper, W. W.; Rhodes, E. 1978. Measuring the efficiency of decision making units, European Journal of Operational Research 2: 429-444. http:// dx.doi.org/10.1016/0377-2217(78)90138-8

Choi, S. 1998. A housing market in the making, China Business Review 25(6): 14-19.

Chung, K. H.; Pruitt, S. W. 1994. A simple approximation of Tobin's Q, Financial Management 23(3): 7074. http://dx.doi.org/10.2307/3665623

Cooper, W. W.; Seiford, L. M.; Tone, K. 2007a. Data envelopment analysis: a comprehensive text with models, applications, references and Dea-Solver software. Kluwer Academic Publishers.

Cooper, W. W.; Lewin, Y.; Seiford, L. M. (Eds.). 2007b. Data envelopment analysis: theory, methodology and applications. Boston: Kluwer Academic Publishers.

Coelli, T. J. 1996. A guide to DEAP Version 2.1: a data envelopment analysis (computer) program, CEPA Working Paper 96/08. Department of Econometrics, University of New England, Armidale.

Coelli, T.; Rao, D. S. P.; O’Donnel, C. J.; Battese, G. E. 2005. An introduction to efficiency and productivity analysis. $2^{\text {nd }}$ ed. New York: Springer. 
Eckbo, B.; Masulis, R.; Norli, O. 2000. Seasoned public offerings: resolution of the 'New Issues Puzzle', Journal of Financial Economics 56: 251-291. http://dx.doi.org/10.1016/S0304-405X(00)00041-6

Fama, E.; Fisher, L.; Jensen, M.; Roll, R. 1969. The adjustment of stock prices to new information, International Economic Review 10: 1-21. http://dx.doi. org/10.2307/2525569

Fama, E. 1991. Efficient capital markets: II, Journal of Finance 46: 1575-1617. http://dx.doi. org/10.1111/j.1540-6261.1991.tb04636.x

Fama, E. F. 1998. Market efficiency, long-term returns, and behavioral finance, Journal of Financial Economics 49: 283-306. http://dx.doi.org/10.1016/S0304405X(98)00026-9

Färe, R.; Grosskopf, S.; Lovell, C. A. K. 1994a. Production frontiers. New York and Cambridge: Cambridge University Press.

Färe, R.; Grosskopf, S.; Norris, M.; Zhang, Z. 1994b. Productivity growth, technical progress and efficiency change in industrialized countries, American Economic Review 84: 66-83.

Färe, R.; Grosskopf, S.; Roos, P. 1998. Malmquist productivity indexes: a survey of theory and practice, in Färe, R.; Grosskopf, S.; Russell, R. R. (Eds.). Index numbers: essays in honour of Sten Malmquist. Boston: Kluwer Academic Publishers. http://dx.doi. org/10.1007/978-94-011-4858-0_4

Farrell, M. J. 1957. The measurement of productive efficiency, Journal of Royal Statistical Society A 120: 253-281. http://dx.doi.org/10.2307/2343100

Franks, J. R.; Harris, R. S. 1989. Shareholder wealth effects of corporate takeovers: the U.K. experience 1955-1985, Journal of Financial Economics 23: 225249. http://dx.doi.org/10.1016/0304-405X(89)90057-3

Healy, P. M.; Palepu, K. G.; Ruback, R. S. 1992. Does corporate performance improve after mergers?, Journal of Financial Economics 31: 135-175. http:// dx.doi.org/10.1016/0304-405X(92)90002-F

Jegadeesh, N.; Karceski, J. 2004. Long-run performance evaluation: correlation and heteroskedas- ticity consistent tests, Working Paper. Emory University.

Jensen, M. C. 1986. Agency costs of free cash flow, corporate finance, and takeovers, American Economic Review 76: 323-329.

Kothari, S. P.; Warner, J. B. 2005. Econometrics of event studies, in Eckbo, B. E. (Ed.). Handbook of corporate finance. empirical corporate finance. Amsterdam: Elsevier/North-Holland.

Kortelainen, M. 2008. Dynamic environmental performance analysis: a Malmquist index approach, Ecological Economics 64: 701-715. http://dx.doi. org/10.1016/j.ecolecon.2007.08.001

Lang, L. H. P.; Stulz, R. M.; Walking, R. A. 1989. Tobin's $\mathrm{Q}$ and gains from successful tender offers, Journal of Financial Economics 24: 137-154. http://dx.doi. org/10.1016/0304-405X(89)90075-5

Lang, L. H. P.; Stulz, R. M.; Walking, R. A. 1991. A test of the free cash hypothesis, Journal of Financial Economics 29: 315-335. http://dx.doi.org/10.1016/0304405X(91)90005-5

Mitchell, M.; Stafford, E. 2000. Managerial decisions and long-term stock price performance, Journal of Business 73: 287-329. http://dx.doi.org/10.1086/209645

Mitchell, M.; Pulvino, T.; Stafford, E. 2004. Price pressure around mergers, Journal of Finance 58: 31-63. http://dx.doi.org/10.1111/j.1540-6261.2004.00626.x

Servaes, H. 1991. Tobin's Q and the gains from takeovers, Journal of Finance 46: 409-419. http://dx.doi. org/10.1111/j.1540-6261.1991.tb03758.x

Shepherd, R. W. 1970. Theory of cost and production functions. Princeton: Princeton University Press.

Sudarsanam, S.; Holl, P.; Salami, A. 1996. Shareholder wealth gains in mergers: effect of synergy and ownership structure, Journal of Business Finance and Accounting 23: 673-698. http://dx.doi. org/10.1111/j.1468-5957.1996.tb01148.x

Zero2IPO Group. 2011. Chinese real estate $M \& A$ deals from 2006 to 2011 (Jan to Feb), Zero2IPO Research Center, March 2011. 